\title{
超音波測定による大腿前面の筋の硬さと膝伸展筋力の関係

\author{
Relationship between Knee Extension Strength and the Quadriceps Femoris Muscle \\ Stiffness Measured by Ultrasound
}

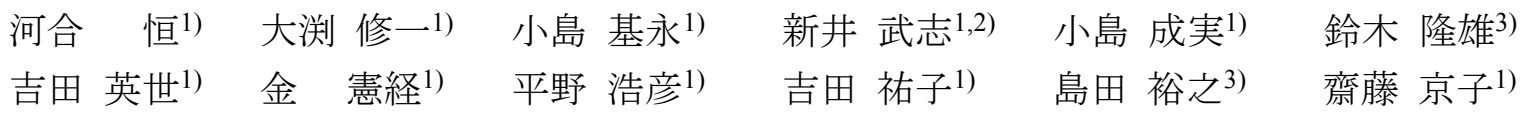

Hisashi KAWAI, PhD ${ }^{1)}$, ShUichi OBUCHI, RPT, $\mathrm{PhD}^{1)}$, Motonaga KOJIMA, RPT, $\mathrm{PhD}^{1)}$, TAKeShi ARAI, RPT, PhD ${ }^{1,2)}$, NARUMI KOJIMA, MS ${ }^{1)}$, TAKAO SUZUKI, MD ${ }^{3)}$, HIDEYO YOSHIDA, MD ${ }^{1)}$, HUNKYUNG KIM, PhD ${ }^{1)}$, HIROHIKO HIRANO, DMD $^{1)}$, YuKo YOSHIDA, PhD ${ }^{1)}$, HIROYUKI SHIMADA, RPT, PhD ${ }^{3)}$, KYOKO SAITO, $\mathrm{PhD}^{1)}$

1) Tokyo Metropolitan Geriatric Hospital and Institute of Gerontology: 35-2 Sakae-cho, Itabashi-ku, Tokyo 173-0015, Japan. TEL+81 3-3964-3241 (ext.2566)FAX+813-5375-5310E-mail hkawai@tmig.or.jp

2) Faculty of Health Sciences, Mejiro University

3) Research Institute, National Center for Geriatrics and Gerontology

Rigakuryoho Kagaku 25(6): 969-975, 2010. Submitted Jun. 21, 2010. Accepted Aug. 24, 2010.

ABSTRACT: [Purpose] To safely estimate knee extensor strength in the elderly, we examined whether or not ultrasound imaging measurement of quadriceps muscle thickness and stiffness enhanced the estimation of knee extensor strength. [Subjects] The subjects were 240 community-dwelling elderly day-service users aged over 65 years (average \pm SD: $80.6 \pm 4.8$ ) with different exercise frequencies and daily living habits. [Methods] Quadriceps muscle thickness and stiffness were measured by an ultrasound imaging system. Knee extensor strength, body mass index, hand-grip strength, one-legged standing with eyes open, and 5-m walking test (normal and maximum) were measured. Exercise frequency and daily living habits were evaluated by questionnaires. [Results] When knee extensor strength was a dependent variable and the independent variables included sex, quadriceps thickness, and quadriceps stiffness, a statistically significant regression equation was derived by multiple linear regression analysis $(\mathrm{R}=0.508$, adjusted $\mathrm{R}^{2}=0.248$ ). When variables related to physical function and daily living were added to the independent variables, the contribution rate was increased $\left(\mathrm{R}=0.716\right.$, adjusted $\left.\mathrm{R}^{2}=0.486\right)$. [Conclusion] Quadriceps thickness and stiffness did not predict knee extensor strength precisely enough, but prediction accuracy could be increased by adding other variables related to physical function and daily living.

Key words: ultrasound imaging system, muscle stiffness, strength of knee extension

要旨：〔目的〕高齢者の安全な膝伸展筋力の推定のために, 超音波画像計測装置を用いて測定した大腿筋厚および 筋の硬さにより，膝伸展筋力推定の寄与率が高まるか検討した。〔対象〕65歳以上の運動習慣，生活状況の異なる 地域在住高齢者とデイサービス利用者 240 名とした (平均年齢 $80.6 \pm 4.8$ 歳)。〔方法〕対象の大腿筋厚と大腿筋厚変 化率を超音波画像計測装置により測定した。体格や運動機能に関する指標として, 膝伸展筋力, BMI, 握力, 開眼 片足立ち時間， $5 \mathrm{~m}$ 歩行時間（通常・最大）を測定した。また，運動習慣，生活状況について質問紙にて聴取した。 [結果] 膝伸展筋力を従属変数, 性別, 大腿筋厚, 大腿筋厚変化率を独立変数とした重回帰分析の結果, $\mathrm{R}=0.508$, adjusted $\mathrm{R}^{2}=0.248$ の統計学的に有意な回帰式を得た。これに運動機能や生活状況に関する変数を加えると, $\mathrm{R}=0.716$, adjusted $\mathrm{R}^{2}=0.486$ であった。〔結語〕膝伸展筋力を予測する因子としては, 大腿筋厚に大腿筋厚変化率を加えても寄 与率は低いが, 他の運動機能や生活状況に関する指標を付加することで膝伸展筋力の予測能力を高めることができる。 キーワード：超音波画像計測装置，筋の硬さ，膝伸展筋力

1) 東京都健康長寿医療センター：東京都板橋区栄町35-2（テ 173-0015）TEL 03-3964-3241 (ext.2566) FAX 03-5375-5310

2) 目白大学 保健医療学部理学療法学科 3 ) 国立長寿医療研究センター研究所

受付日 2010年6月21日受理日 2010年8月24日 


\section{I.はじめに}

高齢者の運動機能評価指標の一つに膝伸展筋力が用 いられる。これは高齢期の生活機能の維持・向上には 下肢筋力が重要であることが, 長期縦断研究1)などの 結果から明らかになっているためであり，介護予防の ための運動介入の効果測定などに広く用いられている。 しかし, 虚弱高齢者に対して膝伸展筋力の測定を実施 する際には，低下した身体状況の影響から，最大の筋 力発揮を求める際に, 関節周囲に一時的な負荷が加わ り, 関節組織に損傷を与える危険性や十分な指導を行っ た場合でも測定中に被験者が一時的に呼吸を止めてし まい，バルサルバ効果による血圧の急激な上昇と下降 のため循環器系へ負担を与える危険性がある2,3)。した がって, 虚弱高齢者に対して従来よりも安全に膝伸展 筋力を推定できる指標を模索することは重要であると 考えられる。

近年, 超音波計測によって筋肉量（あるいは厚さ， 大きさ，走行）を容易に定量できるようになった ${ }^{4-6)}$ 。 筋力は筋断面積に比例することから ${ }^{7)}$, 超音波計測を 応用することによって, 最大努力を必要とする膝伸展 筋力を直接測定すること無しに推定できる可能性を示 すものである。我々はこれまでに, 超音波測定によっ て得られた大腿前面の筋厚と膝伸展筋力との関係を調 べ，大腿前面の筋厚は膝伸展筋力と有意な正の相関が あるものの, 膝伸展筋力を予測する因子としては寄与 率が低く, 寄与率を高める他の指標を探索する必要が あることを指摘した ${ }^{8)}$ 。従来の研究においても, 大腿前 面の筋厚は筋力などの身体機能と相関が高いことを報 告しているが, 推定に利用できるとするものはない3,9-11)。

ところで, 超音波測定から得られるのは筋厚だけで はなく, 一定荷重を加えた際の筋変位, 寸なわち筋の 硬さ指標を測定できることが考えられる。従来，筋の 硬さ測定に用いられる装置には, 皮膚表面に荷重と押 し付け変位を計測できる弾力検出センサを押し当て, 弾性係数を求める筋硬度計があるが 12,13$)$, この測定で は，皮膚，皮下脂肪，筋といった，それぞれ弾性係数 が異なる組織の硬さを総合的に求めているにすぎない。 超音波測定は荷重を加えた際のこれらの組織の変化を 画像によって個々に捉えることができるので，筋その ものの硬さを測定できると期待される。

これまでに村木ら ${ }^{14)}$ は, 超音波粘弾性測定装置を開 発し, 筋厚, 筋の硬さによって筋力推定ができないか 検討している。その結果, 大腿前部の筋厚に, 大腿前 部の筋の硬さを加えると, 膝伸展筋力の推定能力が高
まると報告している。しかし，この研究は18～39歳の 若い年齢を対象としており，この結果が高齢者へ外挿 できるかは不明である。したがって，超音波測定によ る筋の硬さが, 高齢者の筋力推定に有用であるかどう かについては, 高齢者を対象に改めて検討する必要が ある。また, 速筋線維と遅筋線維の比など, 筋肉の性 質は運動習慣や生活状況の違いによって差が生じる。 このような事から同じ厚さの筋であっても, 筋出力に 違いを生じる可能性もあることから, 筋力の推定に, 前述に加えて外出頻度や定期的な運動頻度などの生活 習慣の情報を付加することによって, 推定の精度が増 すかどうかについても調べる必要があると考えられる。

そこで, 本研究では, 運動習慣や生活状況の異なる 高齢者の大標本を対象として, 超音波計測装置を用い て大腿筋厚および筋の硬さを測定した。そして, 筋厚 に加えて, 筋の硬さの情報を付け加えることによって, 膝伸展筋力推定の寄与率が高まるかどうかを再検証し た。さらに，これで十分でない場合には，どのような 運動機能や身体活動状況などの情報を付加すると寄与 率が高まるのか検討することを目的とした。

\section{II. 対象と方法}

\section{1. 対象}

対象は, 65 歳以上の自立歩行可能な地域在住高齢者 と一部デイサービス利用者で，包括的な生活機能調査 (以下，お達者健診）に参加した者の中から以下の条件 に合致したものを男女それぞれ無作為に20名抽出し超 音波計測を行った。抽出には, PASW Statistics 17.0J の ケースの無作為抽出機能を用いた。すべての対象は, 調査内容の説明を受け, 書面による調査参加への意志 を示した。なお，この調査計画は，機関の倫理委員会 において審議され，承認された。

・運動上級者：運動・スポーツを定期的にしている者。

・運動中級者：運動上級者以外で軽い体操を毎日して いる者。

・運動初級者：運動上級者かつ運動中級者以外で散歩 を週 1 回以上している者。

- 運動習慣のない健常高齢者 : 運動上級者かつ運動中 級者かつ運動初級者以外で, 要介護認定を受けてい ないもので，基本チェックリスト該当数が 10 項目未 満の者。

・特定高齢者候補者：要介護認定を受けていない者で, 基本チェックリスト該当数が 10 項目以上の者。

・要支援・要介護者: 要介護認定を受けている者（お 
達者健診参加者のみでは必要数に満たなかったため, 東京近郊のデイサービス利用者を含む)。

なお, 以下の基準に合致するものはお達者健診の対 象から除外した。

除外基準 :

・急性の心臓発作または脳卒中発作の既往のある者

・急性の肝機能障害または慢性のウイルス性肝炎の 活動期である者

・糖尿病があり, 網膜症や腎症など重篤な合併症の ある者

・収縮期血圧 $180 \mathrm{mmHg}$ 以上または拡張期血圧 $100 \mathrm{mmHg}$ 以上の者

- 急性期の整形外科的疼痛および神経症状のある者

・認知症で, 研究参加が不可能であると思われる場合

・そのほか, 研究参加が困難であると認められた者

上記の要件に合致する 240 名（6条件, 男女それぞれ 20 名ずつ）が分析の対象となった。対象の平均年齢は $80.6 \pm 4.8$ 歳（平均值士標準偏差）であった。

\section{2. 方法}

抽出された対象者の膝伸展筋力, 超音波測定から得 られる指標, 体格に関する指標, その他運動機能に関 する指標, 運動習慣, 生活状況に関する指標を測定した。

膝伸展筋力は, 被験者は十分な高さのある椅子に端 座位姿勢をとり, 下腿部を下垂させ膝関節を 90 度屈曲 させた開始姿勢から，利き足または麻瘏や痛みがなく 強い力を出せる側の等尺性最大膝関節伸展筋力を測定 した。測定には, 膝関節の角度, 測定位置を自由に変 えることのできる専用のフレームを用いた。力量計は 簡易型膝伸展筋力測定器 (IsoforceGT610S: OG 技研社 製）を用いフレームに強固に固定した。また，関節裂 隙から, 脛骨長軸上で筋力測定器の中央までの距離を 測定した (以下, 下腿長)。測定は十分な休息を挟んで 2 回行い大きい值を記録とし, 得られた力に下腿長を乗 じて膝関節伸展卜ルク $(\mathrm{Nm})$ を算出した。なお, 下肢 長は, 膝裂隙から力量計の中央までとし, トレーニン グされた検者により身体計測用メジャーで測定した。

超音波測定から得られる指標の測定では, 超音波測 定装置（みるキューブ，グローバルヘルス社製）の超 音波プローブ（以下，プローブ）に力量計を組み込み, プローブの組織に対する圧迫力が測定できるようにし た。被験者は椅子に座って膝関節 90 度屈曲させた姿勢 をとり, 足を床につけて筋を他緩させた。膝伸展筋力 の測定と同じ側の足の膝蓋骨上縁から大腿骨の長軸に 沿って $10 \mathrm{~cm}$ 近位の大腿四頭筋部を, 筋線維走行に垂直
にプローブを当て記録した。圧迫力は，通常超音波撮 影を行うのと同等の圧迫力 $(0.25 \sim 0.35 \mathrm{kgf})$ から, お よそ3秒ごとに段階的に $1 \mathrm{kgf}, 2 \mathrm{kgf}$ と圧迫力を増加さ せながら 10 秒間測定した。

分析では, $0.25 \mathrm{kgf}$ から $0.35 \mathrm{kgf}$ 圧迫時 (以下, 通常 時）の皮下脂肪下の筋膜から骨までの距離を大腿筋厚 と定義した。さらに, 通常時と $2 \mathrm{kgf}$ 荷重時の筋厚の差 を, 通常時の筋厚で除して100を掛けたものを筋厚変化 率（\%）と定義した。村木らの報告 ${ }^{14)}$ においても，同 様に一定圧迫力を加えた際の筋変位量から筋の硬さ指 標を求めている。村木らは圧迫力を約 $1 \mathrm{kgf}$ としだ, 本研究では, 予備試験により大腿前部に加圧した際に

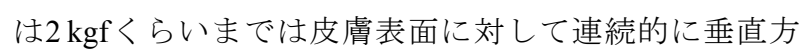
向の変形が続く事がわかり, より大きな筋の変形を捉 えて誤差を最小にする目的で, $2 \mathrm{kgf} を$ 加えた際の筋変 化量をもとにした。

体格に関する指標は, 身長と体重から BMIを求めた。 その他の運動機能に関する指標として, 握力, 開眼 片足立ち時間, $5 \mathrm{~m}$ 通常歩行時間, $5 \mathrm{~m}$ 最大歩行時間を 測定した。運動機能測定については先行研究で用いら れたものと同じ方法で測定した7)。

運動習慣, 生活状況に関する指標として, 老研式活 動能力指標 ${ }^{15)}$, 杖や歩行器の使用, 膝の痛み, 外出の 頻度, 定期的な散歩頻度, 定期的な体操頻度, 定期的 な運動・スポーツの頻度, 連続歩行, 重量物挙上, 階 段昇降に対するセルフエフィカシーを質問紙にて聴取 した ${ }^{16)}$ 。質問項目が多かったことから，(参考資料）の ごとくに簡略化したものを用いた。

老研式活動能力指標は, 「はい」を1点, 「いいえ」を 0 点とし, 合計点 (13 点満点) を算出した。杖や歩行器 の使用については, 「ふだん歩く時に, 杖や歩行器を 使っていますか」の問に対して,「全く歩行できない」, 「使っている」,「使っていない」から選択することとし た。膝の痛みについては, JKOM (Japan Knee Osteoarthritis Measure：日本語版変形性膝関節症患者機能評価表） $\left.{ }^{17}\right)$ の痛みやこわばりに関する質問（問 1〜8）に対して, 最も痛みやこわばりがないものに 1 点, 最も痛みやこ わばりがあるものを 5 点とし, 合計得点を求めた（5点 が最も痛みが少なく, 40 点が最も痛みがある)。外出の 頻度は, 「ふだん, 仕事・買い物・散歩・通院などで外 出する (家の外に出る) 頻度はどのくらいですか」の 問で，「1 日 1 回以上」を 1 点, 「2 3 日に 1 回程度」を 2 点, 11 週間に 1 回程度」を 3 点,「ほとんど外出しない」 を4 点とした。散歩（体操）の頻度については, 「散歩 (軽い体操) を定期的にしていますか。 1 週間に何日く 
$<$ 参考資料 $>$

[セルフエフィカシーの聴取に用いた質問と選択肢］

現在のあなたのさまざまな活動を行うことに対する自信 の程度をお聞きします。《実際に行っているかどうかは別 です。》

A. ゆっくり止まらずにどのくらい歩く自信がありますか。

1. 5 分間歩く自信がある

2. 15 分間歩く自信がある

3. 30 分間歩く自信がある

4. 45 分間歩く自信がある

5. 60 分間歩く自信がある

0.いずれも自信がない

B. 1階が 14 １6段ある階段を休まずにどのくらい昇る自 信がありますか。

1. 2階まで昇る自信がある

2. 3 階まで昇る自信がある

3.4階まで昇る自信がある

4. 5 階まで昇る自信がある

5. 6階まで昇る自信がある

0.いずれも自信がない

C. 両腕で重量物をどのくらいまで持ち上げる自信があ りますか。

1. $1 \mathrm{~kg}$ の物を持ち上げる自信がある

2. $2 \mathrm{~kg}$ の物を持ち上げる自信がある

3. $3 \mathrm{~kg}$ の物を持ち上げる自信がある

4. $5 \mathrm{~kg}$ の物を持ち上げる自信がある

5. $10 \mathrm{~kg}$ の物を持ち上げる自信がある

0. いずれも自信がない

らいしていますか」の問で，「毎日」を1点，「5〜6日」 を2点，「2〜4日」を 3 点，「1日以下」を 4 点，「散歩（体 操）はしていない」を5点とした。運動・スポーツの実 施頻度については，「運動・スポーツなどを定期的にし ていますか」の問で，「している」に1点，「していない」 に2 点を与えた。セルフエフィカシーについては, 階段 昇降，重量物の持ち上げ，連続歩行に関するセルフエ フィカシーのそれぞれの問に対して, 自信がない回答 から最も自信がある回答まで 0 〜点を与えた（15 点満 点)。

統計解析は, 膝伸展筋力, 大腿前面の筋厚, 筋厚変 化率と, 体格, 運動機能に関する指標, 運動習慣, 生 活状況に関する指標の各変数との関係をSpearmanの $\rho$ を用いて調べた。膝伸展筋力の推定には，まず，村木 らの研究 ${ }^{14)}$ と同様の方法で, 膝伸展筋力を従属变数, 性別, 大腿筋厚を独立変数とした重回帰分析を行い, これに大腿筋厚変化率を加えることで, 推定能力が高 まるかを調べた。さらに, 膝伸展筋力を従属変数とし,
前記の単回帰分析の結果，有意な相関を認めた変数を 独立変数とした重回帰分析を行い，その他の変数を加 えることで推定能力が上昇するかどうか検討した。本 研究で扱った全ての変数でどれくらいの寄与率がある か確認するため，まず，強制投入法を用い，次に，強 制投入法で求めたモデルを大きく損なわない範囲で, 変数を選択するとどうなるか検討するため, 変数減少 法を用いた。なお, 質問紙にて聴取した項目のうち, 杖 や歩行器の使用については, ダミー変数として分析に 投入した。運動頻度や他の質問紙調査項目については, そのまま投入した。

さらに, 重回帰分析によって得られた回帰式の誤差 を評価するために, 以下の式により推定誤差を算出した。

推定誤差 $(\mathrm{Nm})=\mid$ 膝伸展筋力の実測值一推定值 $\mid$

推定誤差 $(\%)=\mid$ 膝伸展筋力の実測值一推定值 $\mid$

実測值 $\times 100$

統計学的な有意水準は 5\%未満とした。全ての統計処 理にはPASW Statistics 17.0Jを用いた。

\section{III. 結 果}

各測定項目の平均值を表 1 に示した。被験者の身体 状態を考慮したうえで実施できる項目を選択したため, 表1には測定できた被験者についての平均值を示した。

各変数との超音波から得られる指標, 膝伸展筋力と の相関を表 2 に示した。膝伸展筋力と統計学的に有意 な相関が認められたのは, 年齢 $(r=-0.132)$, BMI $(r=$ $-0.158)$, 握力 $(\mathrm{r}=0.691)$, 通常歩行時間 $(\mathrm{r}=-0.485)$, 最 大歩行時間 $(r=-0.524)$, 開眼片足立ち時間 $(r=0.339)$, 大腿筋厚 $(\mathrm{r}=0.140)$, 大腿筋厚変化率 $(\mathrm{r}=-0.155)$, 老研 式活動能力指標 $(r=0.200)$, 杖や歩行器の使用 $(r=0.220)$, JKOM（r=-0.294），セルフエフィカシー $(\mathrm{r}=0.527)$ で あった。一方，大腿筋厚と有意な相関が認められた変 数は, 年齢 $(\mathrm{r}=-0.211), \mathrm{BMI}(\mathrm{r}=0.588)$, 握力 $(\mathrm{r}=0.147)$, 最大歩行時間 $(\mathrm{r}=-0.148)$, セルフエフィカシー $(\mathrm{r}=0.147)$, 膝伸展筋力 $(r=0.140)$ であった。大腿筋厚変化率と統 計学的に有意な相関を認めた変数は, BMI $(\mathrm{r}=-0.136)$, 握力 $(\mathrm{r}=-0.228)$, 杖や歩行器の使用 $(\mathrm{r}=-0.148)$, セル フエフィカシー $(\mathrm{r}=-0.153)$, 膝伸展筋力 $(\mathrm{r}=-0.155)$ で あった。

䊫伸展筋力を従属変数, 性別, 大腿筋厚を独立変数 とした重回帰分析を行ったところ， R=0.505, adjusted $\mathrm{R}^{2}=0.249$ の統計学的に有意な回帰式を得た。これに大 腿筋厚変化率を加えた場合には $\mathrm{R}=0.508$, adjusted $\mathrm{R}^{2}=$ 
表1 対象者の基本情報

\begin{tabular}{|c|c|c|c|}
\hline 項目 & $\mathrm{n}$ & 平均値士標準偏差 & 範囲 \\
\hline 年齢 (歳) & 240 & $80.6 \pm 4.79$ & $65-95$ \\
\hline 身長 (cm) & 240 & $154.0 \pm 8.87$ & $129.1-176.3$ \\
\hline 体重 $(\mathrm{kg})$ & 240 & $53.4 \pm 9.89$ & $32.3-95.5$ \\
\hline BMI & 240 & $22.4 \pm 3.19$ & $15.1-35.3$ \\
\hline 握力 (kg) & 231 & $23.9 \pm 7.97$ & $1-50$ \\
\hline 開眼片足立ち時間 (秒) & 236 & $26.5 \pm 22.42$ & $0-60$ \\
\hline 通常歩行時間(秒) & 235 & $4.7 \pm 2.10$ & $2.5-27.5$ \\
\hline 最大歩行時間(秒) & 224 & $3.2 \pm 1.36$ & $1.8-16.0$ \\
\hline 膝伸展筋力 (Nm) & 229 & $63.0 \pm 28.08$ & $3.8-174.6$ \\
\hline 大腿筋厚 (mm) & 240 & $15.1 \pm 4.25$ & $6.2-29.9$ \\
\hline 大腿筋厚変化率 (\%) & 240 & $26.2 \pm 9.44$ & $2.4-56.5$ \\
\hline 老研式活動能力指標 & 233 & $12.0 \pm 1.68$ & $4-13$ \\
\hline 杖や歩行器の使用 & 222 & $1.8 \pm 0.41$ & $0-2$ \\
\hline JKOM & 238 & $12.7 \pm 5.82$ & $8-40$ \\
\hline 外出の頻度 & 222 & $1.3 \pm 0.51$ & $1-4$ \\
\hline 定期的な散歩頻度 & 222 & $3.1 \pm 1.76$ & $1-5$ \\
\hline 定期的な体操頻度 & 222 & $3.0 \pm 1.78$ & $1-5$ \\
\hline $\begin{array}{l}\text { 定期的な運動・ } \\
\text { スポーツ頻度 }\end{array}$ & 222 & $1.8 \pm 0.44$ & $1-2$ \\
\hline セルフエフィカシー & 232 & $10.2 \pm 3.17$ & $1-15$ \\
\hline
\end{tabular}

0.248 であった。

さらに, 膝伸展筋力と有意な相関が認められた変数 のうち, 膝伸展筋力と同様に組織の損傷やバルサルバ 効果のリスクがあると考えられる握力, 最大努力での 歩行が必要な最大歩行時間を除外し, 残りの変数 (年 齢, BMI, 通常歩行時間, 開眼片足立ち時間, 老研式活 動能力指標, 杖や歩行器の使用, JKOM, セルフエフィ カシー）および性別, 大腿筋厚 大腿筋厚変化率を独 立変数, 膝伸展筋力を従属変数とした重回帰分析を行っ た結果, 強制投入法では $\mathrm{R}=0.716$, adjusted $\mathrm{R}^{2}=0.486$ の統 計学的に有意な回帰式を得た（表 3）。この回帰式によ り得られた膝伸展筋力の推定誤差 $(\mathrm{Nm}, \%)$ は, 平均 值で $13.4 \mathrm{Nm}, 26.8 \%$ であった。

そして最終的に, 変数減少法によって同様の分析を 行った場合, 性別, BMI, 開眼片足立ち時間, JKOM, セルフエフィカシーが選択され, $\mathrm{R}=0.707$, adjusted $\mathrm{R}^{2}=0.488$ となった。

\section{IV. 考 察}

本研究では, 運動習慣や生活状況の異なる高齢者の 大標本を対象として, 超音波計測装置を用いて大腿筋 厚および筋の硬さを測定し, 筋厚に加えて, 筋の硬さ
表2 各変数と超音波測定から得られる指標および膝伸展筋 力との相関

\begin{tabular}{lccc}
\hline & $\begin{array}{c}\text { 膝伸展筋力 } \\
(\mathrm{Nm})\end{array}$ & $\begin{array}{c}\text { 大腿筋厚 } \\
(\mathrm{mm})\end{array}$ & $\begin{array}{c}\text { 大腿筋厚 } \\
\text { 変化率 }(\%)\end{array}$ \\
\cline { 2 - 4 } & \multicolumn{3}{c}{$\mathrm{r}$} \\
\hline 年齢（歳） & $-0.132^{*}$ & $-0.211^{* *}$ & 0.039 \\
$\mathrm{BMI}$ & $0.158^{*}$ & $0.588^{* *}$ & $-0.136^{*}$ \\
握力 $(\mathrm{kg})$ & $0.691^{* *}$ & $0.147^{*}$ & $-0.228^{* *}$ \\
通常歩行時間（秒） & $-0.485^{* *}$ & -0.127 & 0.073 \\
最大歩行時間（秒） & $-0.524^{* *}$ & $-0.148^{*}$ & 0.091 \\
開眼片足立ち時間（秒） & $0.339^{* *}$ & 0.083 & -0.092 \\
老研式活動能力指標 & $0.200^{* *}$ & 0.086 & -0.054 \\
杖や歩行器の使用 & $0.220^{* *}$ & 0.029 & $-0.148^{*}$ \\
JKOM & $-0.294 * *$ & -0.045 & 0.041 \\
外出の頻度 & -0.049 & -0.088 & 0.046 \\
定期的な散歩頻度 & -0.133 & -0.003 & 0.072 \\
定期的な体操頻度 & -0.088 & 0.082 & 0.008 \\
定期的な運動・ & -0.124 & 0.010 & 0.020 \\
スポーツ頻度 & & & \\
セルフエフィカシー & $0.527 * *$ & $0.147^{*}$ & $-0.153^{*}$ \\
膝伸展筋力（Nm） & - & $0.140^{*}$ & $-0.155^{*}$ \\
大腿筋厚（mm） & $0.140^{*}$ & - & 0.023 \\
大腿筋厚变化率（\%) & $-0.155^{*}$ & 0.023 & - \\
\hline
\end{tabular}

$* * \mathrm{p}<0.01, * \mathrm{p}<0.05$

表3 膝伸展筋力を従属変数とした重回帰分析 (強制投入法) の結果

重相関係数 $(\mathrm{R})=0.716$, 自由度調整済み決定係数 $\left(\right.$ adjustedR $\left.^{2}\right)$ $=0.486$

推定值の標準誤差 $=17.64$

\begin{tabular}{|c|c|c|c|}
\hline $\begin{array}{l}\text { 従属変数 } \\
(=\text { =膝伸展筋力 })\end{array}$ & $\begin{array}{c}\text { 非標準化 } \\
\text { 回帰係数 (B) }\end{array}$ & $\begin{array}{c}\text { 標準化 } \\
\text { 偏回帰係数 }(\beta) \\
\end{array}$ & $\mathrm{p}$ \\
\hline （定数） & 30.869 & 0.411 & \\
\hline 性別 & 24.624 & 0.502 & 0.000 \\
\hline 大腿筋厚 $(\mathrm{mm})$ & -0.27 & -0.046 & 0.502 \\
\hline 大腿筋厚変化率 (\%) & -0.084 & -0.033 & 0.540 \\
\hline 年齢 (歳) & -0.535 & -0.087 & 0.160 \\
\hline BMI & 2.138 & 0.286 & 0.000 \\
\hline 通常歩行時間(秒) & -0.192 & -0.016 & 0.796 \\
\hline 開眼片足立ち時間 (秒) & 0.172 & 0.154 & 0.013 \\
\hline 老研式活動能力指標 & 0.487 & 0.034 & 0.543 \\
\hline 杖や歩行器の使用 & 5.278 & 0.084 & 0.175 \\
\hline JKOM & -0.481 & -0.111 & 0.065 \\
\hline セルフエフィカシー & 1.768 & 0.228 & 0.001 \\
\hline
\end{tabular}

の情報を付け加えることによって, 膝伸展筋力推定の 寄与率が高まるかどうかを再検証した。さらに, どの 
ような運動機能や身体活動状況などの情報を付加する

と寄与率が高まるのか検討した。

膝伸展筋力を従属変数, 性別と大腿筋厚を独立変数 とした重回帰分析では, 膝伸展筋力を推定する有意な 回帰式を得られたものの, $\mathrm{R}=0.505$, adjusted $\mathrm{R}^{2}=0.249$ で あった。これに大腿筋厚変化率を加えると, $\mathrm{R}=0.508$, adjusted $\mathrm{R}^{2}=0.248$ で，ほとんど推定能力は上がらなかっ た。本研究と同様に, 膝伸展筋力を従属変数, 性別, 筋 厚, 筋厚変化率を独立変数とした重回帰分析を $18 \sim 39$ 歳の若い年齢を対象として行った村木らの研究14)では, $\mathrm{R}=0.833$ の回帰式を得て, 筋厚に筋の硬さの情報を加え ることで膝伸展筋力の推定能力が高まるとしているが, 本研究ではそのような結果は得られなかった。大腿筋 厚と膝伸展筋力の関係, 大腿筋厚変化率と膝伸展筋力 の関係を散布図で調べると, 村木らの報告と比べると 個人差が大きく, 相関もそれほど高くない。本研究の 対象は, 運動習慣や生活状況の異なる高齢者であり, これらの高齢者においては筋厚や硬さの個人差が若年 層と比べて大きいため, 筋厚に筋の硬さを加えても, 膝伸展力の予測には不十分であったことが考えられる。 すなわち, 高齢者においては, 筋厚や筋の硬さだけか ら膝伸展筋力を推定することは, 若年層に比べて難し いことが示唆される。

そこで, 本研究では, 体格や運動機能や運動習慣, 生活状況に関する指標を加えて, どのような指標が膝 伸展筋力の予測を高めるか検討した。

性別, 大腿筋厚, 大腿筋厚変化率に加えて, 膝伸展 筋力と統計学的に有意な相関を認めた変数のうち, 本 研究の目的（安全な膝伸展筋力の推定指標の模索）に 合致する変数 (年齢, BMI, 通常歩行時間, 開眼片足立 ち時間, 老研式活動能力指標, 杖や歩行器の使用, JKOM, セルフエフィカシー）を独立変数として, 膝伸展筋力 を従属変数とした重回帰分析を再度行うと, 膝伸展筋 力を推定する有意な回帰式を得ることができ，寄与率 を高めることもできた $\left(\mathrm{R}=0.716\right.$, adjusted $\left.\mathrm{R}^{2}=0.486\right)$ 。し たがって, 高齢者の膝伸展筋力の推定には, 大腿筋厚 や筋厚変化率に, 運動機能や体格や生活状況などの指 標を付加することで，推定能力を高めることができる 可能性が示された。

この回帰式によって得られた膝伸展筋力の推定誤差 の平均值は $13.4 \mathrm{Nm}(26.8 \%)$ であった。筋力の誤差に ついては, Astrand らが10～20\%の日差変動を示してお り ${ }^{18)}$, 本研究と同様に高齢男女の等尺性膝伸展筋力を 測定した研究 ${ }^{19,20)} に$ にいても, テスト再テスト間の変 動は $10 \%$ 程度認められる。本研究で得られた推定式で
の誤差の平均值と比較すると, 本研究の推定誤差はや や大きいが，推定筋力の分布をみると，筋力の強い者 で誤差が大きくなる傾向があり， $70 \mathrm{Nm}$ 以下くらいの 筋力の低い虚弱高齢者に対しては十分に適用できる精 度があると考えられた。

しかし, 変数減少法による重回帰分析の結果では, 大腿筋厚, 大腿筋厚変化率は除外され, 残った変数は, 性別, 開眼片足立ち時間, BMI, JKOM, セルフエフィ カシーであった。大腿筋厚はBMI と $(\mathrm{r}=0.588)$, 大腿筋 厚変化率はBMI $(\mathrm{r}=-0.136)$, セルフエフィカシーと $(\mathrm{r}=$ -0.163）とそれぞれ統計学的に有意な相関があり, これ らの指標が代わりに選択されたと考えられる。特に, 大腿筋厚は体格の影響が強く, 現時点では, 筇厚測定 はBMI ほど高齢者の膝伸展筋力推定に貢献しないとい うことが示唆された。

しかしながら, 筋厚や筋の硬さは, 筋力に関係する 筋線維の断面積や, 筋線維の状態を反映した重要な指 標と考えられる。本研究では, 村木らの研究における 若年者の結果と比べて, 高齢者では筋厚や筋の硬さか ら膝伸展筋力を推定することは困難であったが, これ は筋厚や筋の硬さ以外の筋力を規定する要因の影響が あることを意味している。したがって, 例えば, 超音 波画像の反射強度から筋線維組織の質を測定し指標を 追加するなど8), 推定精度を高める方法をさらに検討 していく必要がある。

大腿筋厚変化率については, 体格の影響は筋厚に比 べると大きくなく, 握力やJKOMやセルフエフィカシー との相関が認められたことから, 筋力や生活状況を反 映した新たな指標として活用が期待されるものである。 今回の研究では, 村木らの研究に準じて, 一定の圧迫 力を加えた際の筋変位量をもとに筋変化率を算出した が，筋や脂肪に圧迫力を加えた際の時間一変位関係は 線形ではないため, 正確な硬さ指標を求めるためには さらなる検討が必要である。既存の筋硬度計にはすで にこうした特性を組み込んだものがあるように ${ }^{211}$ ，今 後は, 本研究で使用した超音波計測装置についても, 組織の粘弾性特性を考慮した筋の硬さ指標の補正を行 い，筋厚と組み合わせて筋力推定に有用な指標となり うるか，さらに検討していく必要があると考える。

運動習慣, 生活状況の異なる高齢者 240 名を対象に, 超音波測定から得られる大腿の筋厚変化率と, 体格や 運動機能との関連を調心，筋の硬さから膝伸展筋力の 推定が可能か検討した。その結果, 大腿筋厚, 大腿筋 厚変化率は, 膝伸展筋力と統計学的に有意な相関を認 め, 運動機能を反映した指標であることがわかった。 
しかし, 重回帰分析の結果では, 膝伸展筋力を予測す る因子としては, 大腿筋厚に大腿筋厚変化率を加えて も寄与率は低く, 高齢者の膝伸展筋力の推定に利用す るためには不十分であった。高齢者の膝伸展筋力の推 定には, 筋厚や筋の硬さに加え, 他の運動機能や生活 状況に関する指標を付加することで予測能力を高める ことができることが明らかとなった。

\section{引用文献}

1) 東京都老人総合研究所 : 長期プロジェクト研究報告書「中年 からの老化予防総合的長期追跡研究」. 2000.

2) Seals DR, Washburn RA, Hanson PG, et al.: Increased cardiovascular response to static contraction larger muscle groups. J Appl Physiol, 1983, 54: 434-437.

3) 西本哲也, 西本千奈美, 渡邊 進・他 : 等尺性運動, バルサ ルバが健常成人の血圧・心拍に及ぼす影響. 川崎医療福祉学 会誌, 1997, 7: 405-409.

4) 池添冬芽, 浅川康吉, 島 浩人・他 : 加齢による大腿四頭筋 の形態的特徵および筋力の変化について: 高齢女性と若年女 性の比較. 理学療法学, 2007, 34: 232-238.

5) Miyatani M, Kanehisa H, Ito M, et al.: The accuracy of volume estimates using ultrasound muscle thickness measurements in different muscle groups. Eur J Apple Physiol, 2004, 91: 264-272.

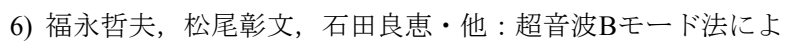
る皮下脂肪厚および筋厚の測定方法の検討. Jpn J Med Ultrasonics, 1989, 16: 170-177.

7) 琉子友男, 福永哲夫 : 等尺性最大筋力に及ぼす筋断面積およ び筋線維組成の影響. 体力科学, 1986, 35(3): 168-174.

8) 大㴊修一, 新井武志, 小島基永 $\cdot$ 他 : 超音波測定による大腿 前面筋厚と膝伸展筋力の関係. 理学療法科学, 2009, 24(2): 185-190.

9) Freilich RJ, Kirsner RL, Byrne E: Isometric strength and thickness relationships in human quadriceps muscle. Neuromuscul Disord, 1995, 5(5): 415-422.
10) Sipila S, Suominen H: Muscle ultrasonography and computed tomography in elderly trained and untrained women. Muscle Nerve, 1993, 16: 294-300.

11) 市橋則明, 大畑光司, 西村 純・他 : 超音波画像解析による 大腿四頭筋の形態的特性と膝伸展筋力の関係. 理学療法学, 2005, 32(Suppl 2): 73.

12) 古後晴基, 黒澤和生, 長谷川敦子・他 : 筋硬度の定量化なら びに筋硬結における筋疼痛と筋硬度との関連性. 理学療法科 学, 2010, 25(1): 41-44.

13) 孫 崗, 宮川俊平, 木下裕光・他 : 成長期女子サッカー選手 における大腿四頭筋の筫硬度の試合前後の変化. 日本臨床又 ポーツ医学会誌, 2008, 16(1): 68-71.

14) 村木里志, 福田 修, 福元清剛: 超音波粘弾性計測装置を用 いた筋力評価の有効性の検討. デサントスポーツ科学, 2009, 30: 105-113.

15) 古谷野亘, 柴田 博, 中里克治・他: 地域老人における活動 能力の測定 ; 老研式活動能力指標の開発. 日本公衆衛生雑 誌, 1987, 34: 109-114.

16) 稲葉康子, 大㴊修一, 岡浩一朗・他：虚弱高齢者の身体活動 セルフ・エフィカシー尺度の開発. 日老医誌, 2006, 43(6): 761-768.

17) Akai M, Doi T, Fujino K, et al.: An outcome measure for Japanese people with knee osteoarthritis. J Rheumatol, 2005, 32(8): 15241532.

18) Astrand PO, Rodahl K: Textbook of work physiology. McGrawHill, 1978.

19) Ford-Smith CD, Wyman JF, Elswick RK Jr, et al.: Reliability of stationary dynamometer muscle strength testing in communitydwelling older adults. Arch Phys Med Rehabil, 2001, 82(8): 11281132.

20) 加藤宗規, 磯崎弘司, 坂上 昇・他：ハンドヘルドダイナモ メーターとベルトを用いた等尺性膝伸展筋力測定の再現性 健常高齢者を対象とした測定-再測定間再現性の検討. 理 学療法学, 2008, 35(Suppl 2): 548.

21) 石川大輔, 内山孝憲 : 小型ディジタル筋硬度計の開発. バイ オメカニズム学会誌，2006, 30(4): 234-237. 